\title{
Induksi Pembentukan Gaharu Menggunakan Berbagai Media Tanam dan Cendawan Acremonium sp. dan Fusarium sp. Pada Aquilaria crassna
}

\author{
TRIADIATI TRIADIATI ${ }^{* *}$, DIANA AGUSTIN CAROLINA ${ }^{1}$, MIFTAHUDIN ${ }^{1}$ \\ ${ }^{1}$ Departemen Biologi, Fakultas Matematika dan Ilmu Pengetahuan Alam, Institut Pertanian Bogor, Kampus \\ Dramaga, 16680
}

Diterima 12 April 2016/Disetujui 8 Juni 2016

\begin{abstract}
Aquilaria crassna is one of the Aquilaria species that could produce agarwood. Agarwood production of $A$. crassna can be induced by microfungi as an inoculant. Ecological interaction between the host plant, wounding and inoculant in the formation of agarwood has not yet clearly. Other factors like the plant ages, plant species, environment also played important roles in the formation of agarwood. This research aimed to determine the influence of the combination between planting media and Acremonium sp. and Fusarium sp. to agarwood quality of Aquilaria crassna. The experiment was consisted of two factors, which were five planting media and two inoculants fungi i.e. Acremonium sp. and Fusarium sp. The observed parameters were the percentage of senescence leaves, color of wood, level of fragrant and terpenoid content. The best agarwood fragrant was produced by the seedlings that were treated with either combination of husk charcoal media enriched with NPK fertilizer and Acremonium sp. or the combination between husk charcoal media enriched with Hoagland modified solution and Fusarium sp.. The darkest color of wood was produced by the seedlings that were treated with combination of husk charcoal media enriched with NPK fertilizer and Acremonium sp., as well as for the same media with Fusarium sp.. During the experiment terpenoid could not be detected from the treated seedlings. Acremonium sp. caused more leave senescence than that of Fusarium sp..
\end{abstract}

Key word: Agarwood, Acremonium, Fusarium, Aquilaria crassna

\section{PENDAHULUAN}

Gaharu adalah sejenis kayu dengan berbagai bentuk dan warna yang khas serta memiliki kandungan kadar damar wangi (BSN 1999). Pohon penghasil gaharu ini berasal dari suku Thymelaeaceae. Anggota suku tersebut telah diketahui sebanyak 8 genus sebagai pohon penghasil gaharu yaitu Aquilaria, Wikstroemia, Gonyistylus, Gyrinops, Dalbergia, Enkleia, Excoccaria, dan Aetoxylon (Tarigan 2004). Gaharu dapat dimanfaatkan sebagai bahan dasar industri parfum, dupa untuk berbagai upacara keagamaan, kosmetik juga obat-obatan (Barden et al. 2000). Selain memiliki banyak kegunaan, gaharu juga memiliki nilai ekonomi yang sangat tinggi. Nilai ekonominya yang tinggi tersebut menyebabkan perburuan gaharu meningkat, sedangkan sampai saat ini, produksi gaharu masih mengandalkan hutan alam yang keberadaannya semakin langka. Selain itu, produksi gaharu secara alami membutuhkan waktu yang cukup lama. Perburuan yang eksplosif tanpa diikuti oleh usaha budidaya yang selaras menyebabkan salah satu spesies Aquilaria, yaitu Aquilaria malaccensis pada tahun 1994 telah ditetapkan masuk dalam daftar CITES Appendix II (Newton \& Suhartono 2001).

Gaharu merupakan deposit resin pada jaringan kayu

${ }^{*}$ Penulis korespondensi : +628121387620

email: adiatiipb@gmail.com sebagai reaksi pohon terhadap pelukaan atau infeksi patogen. Michiho (2005) mengatakan bahwa Senyawa gaharu diakumulasi dalam jumlah besar pada pohon Aquilaria yang sudah tua dan terbentuk terutama pada bagian yang dilukai. Senyawa gaharu dibentuk sebagai respon pertahanan pohon gaharu terhadap berbagai gangguan seperti perlukaan, infeksi patogen atau perlakuan kimiawi (Nobuchi \& Sripatanadilok 1991). Gaharu merupakan senyawa sesquiterpen yang beraroma khas. Aroma gaharu ini diduga merupakan senyawa fitoaleksin (Yuan 1995; Michiho 2005). Fitoaleksin adalah senyawa antimikrob dengan berat molekul rendah yang terakumulasi pada tanaman sebagai reaksi terhadap infeksi dan stress (Merk-Turk 2002). Interaksi ekologis antara pohon inang, perlukaan dan atau jamur dalam pembentukan gaharu masih belum dipahami dengan jelas.

Penelitian untuk meningkatkan kualitas dan kuantitas gaharu sudah banyak dilakukan. Berbagai macam rekayasa produk yang telah dilakukan, antara lain pemberian metil jasmonat (secara berulang) untuk meningkatkan deposit terpenoid dan meningkatkan aroma wangi (Rosita 2008), penggunaan induksi ganda gaharu dengan menggunakan Acremonium sp. dan Fusarium sp. (Wulandari 2009), hingga mengkombinasikan senyawa kimia (asam salisilat, metil jasmonat) dengan Acremonium sp. untuk menginduksi terbentuk senyawa gaharu (Murtaip 2010). Faktor-faktor lain seperti umur pohon, perbedaan spesies pohon, pengaruh musim, variasi lingkungan, dan variasi 
genetik juga berperan penting dalam pembentukan gaharu (Novriyanti 2008). Isnaini (2004) mengatakan bahwa ada Faktor biotik (isolat cendawan) dan faktor abiotik yaitu asam absisat (ABA) berpengaruh dalam mempercepat pembentukan gubal gaharu. Faktor lingkungan yang mempengaruhi pembentukan gaharu di antaranya adalah unsur hara dalam media tanam. Menurut Karyantara (2009), penanaman gaharu pada kombinasi media tanam (tanah, pasir, dan kompos daun kering) mampu meningkatkan pertambahan tinggi dan diameter batang tanaman gaharu. Ketersediaan hara dalam tanah meningkatkan kemampuan tanaman melakukan metabolisme secara primer maupun sekunder. Salah satu unsur hara yaitu $\mathrm{S}$ (sulfur (S), merupakan unsur penyusun dari asam amino sistein dan metionin. Kedua asam amino tersebut merupakan prekursor senyawa koenzim dan metabolit sekunder tanaman. Metabolisme sulfur dapat mempengaruhi pembentukan aroma pada tumbuhan, misalnya pada bawang merah (Allium cepa) melalui pembentukan senyawa alliins. Senyawa Alliins pada bawang dipecah oleh enzim alliinase menjadi Allicins, yang berfungsi sebagai prekursor dari pembentukan senyawa volatil dengan aroma yang khas (Marschner 1995). Namun penelitian tentang pengaruh sulfur terhadap aroma gaharu belum pernah dilakukan, oleh karena itu perlu diteliti tentang pengaruh sulfur dan unsur hara lain terhadap pembentukan senyawa harum pada gaharu. Tujuan dari penelitian ini adalah Penelitian ini bertujuan untuk menginduksi pembentukan gaharu menggunakan berbagai media tanam dan inokulum cendawan Acremonium sp. dan Fusarium sp. pada Aquilaria crassna.

\section{BAHAN DAN METODE}

Bahan. Bahan yang digunakan dalam penelitian ini adalah pohon Aquilaria crassna berumur 8-12 bulan dengan tinggi berkisar antara $30-50 \mathrm{~cm}$, cendawan Acremonium L IPBCC 08.566 dan Fusarium B IPBCC 08.569, arang sekam sebagai media, larutan Hoagland, larutan Hoagland yang telah dimodifikasi yaitu dengan diberi penambahan $1 \mathrm{M} \mathrm{MgSO} 44 \mathrm{ml} / \mathrm{l}$ dan $1 \mathrm{M} \mathrm{NaSO} 44$ ml/l, pupuk NPK 16:16:16, bahan-bahan kimia untuk uji Lieberman-Burchard.

Rancangan Percobaan. Rancangan percobaan yang digunakan dalam penelitian adalah Rancangan Acak Lengkap Faktorial yang terdiri atas dua faktor. Faktor pertama adalah jenis cendawan yaitu Acremonium sp. dan Fusarium sp., sedangkan faktor kedua adalah media tanam dengan pemberian hara yang berbeda, yaitu tanah tanpa pemberian tambahan unsur hara sebagai kontrol (tanah), arang sekam: tanah (1:1 v/v) (Tanah: AS), arang sekam ditambah pupuk NPK (AS+NPK), arang sekam diberi larutan Hoagland $(\mathrm{AS}+\mathrm{H})$, dan arang sekam diberi larutan Hoagland yang dimodifikasi dengan penambahan $\mathrm{MgSO} 4$ dan NaSO4 (AS+HM). Setiap kombinasi perlakuan diulang sebanyak 3 kali. Pengamatan yang dilakukan meliputi persentase daun rontok, kadar harum, kadar warna, dan uji keberadaan terpenoid pada kayu gaharu.

Penanaman dan Pemupukan Aquilaria crassna.
Bibit pohon ditanam di polibag yang diisi media tanam sebanyak 500 g. Pemberian larutan Hoagland dan Hoagland yang dimodifikasi diberikan sebanyak $60 \mathrm{ml} / 2$ hari, sedangkan pupuk NPK diberikan sebanyak $1 \mathrm{gr} /$ polibag/3 minggu (total pemberian dua kali). Media tanam untuk kontrol digunakan tanah latosol. Bibit tanaman $A$. crassna yang ditanam sebagai kontrol disiram dengan air keran $60 \mathrm{ml} / 2$ hari. Bibit tanaman $A$. crassna diberi perlakuan selama $\pm 1,5$ bulan untuk melihat respon tanaman terhadap penyerapan unsur hara.

Induksi cendawan. Pelukaan batang untuk induksi cendawan dilakukan di batang utama. Batang utama dilukai $5 \mathrm{~cm}$ dari permukaan tanah, kulit batang tanaman dikupas dengan ketebalan 1/3 dari ketebalan batang dengan panjang sayatan 1-2 cm. Kemudian bagian yang telah dilukai tersebut ditempeli dengan agar yang mengandung miselium cendawan (Acremonium L IPBCC 08.566 atau Fusarium B IPBCC 08.569 yang telah diinkubasi selama 7 hari). Kemudian batang dibungkus dengan kapas dan ditutup dengan sedotan plastik untuk mencegah aroma cepat menguap. Pelukaan pada batang yang sudah diberi inokulan cendawan disemprot dengan aquades steril setiap hari untuk menjaga kapas tetap lembap bagi cendawan. Perlakuan induksi cendawan dilakukan hingga 1,5 bulan kemudian.

Daun gugur. Jumlah daun pada setiap tanaman dihitung terlebih dahulu sebelum pemberian inokulum cendawan. Jumlah daun yang gugur dihitung pada 1 minggu setelah induksi cendawan. Pengamatan jumlah daun yang gugur diamati tiap hari hingga 1,5 bulan kemudian. Persentase daun yang gugur dihitung menggunakan rumus:

persentase daun gugur $=\frac{\text { jumlah daun yang gugur/tanaman }}{\text { jumlah daun total/tanaman }} \times 100 \%$

Uji Kadar Harum dan Kadar Warna Kayu Gaharu:

Tingkat Harum Kayu. Uji organoleptik dilakukan dengan cara mencium batang yang dilukai. Tingkat wangi dinyatakan dalam rataan skor dari 3 responden. Harum kayu ditetapkan melalui uji organoleptik dengan pemberian skor harum dalam skala $0=$ tidak harum, $1=$ agak harum, 2 = harum, 3 = sangat harum (Rosita 2008). Uji tingkat harum dilakukan setiap hari, mulai hari pertama HSI sampai dengan 14 HSI.

Kadar Warna Kayu. Perubahan warna kayu ditetapkan melalui uji organoleptik terhadap batang kayu yang telah dilukai dengan pemberian skor warna sebagai berikut 0 = putih, 1 = putih kecoklatan, 2 = cokelat, 3 = cokelat kehitaman (Putri 2007). Uji kadar warna kayu dilakukan oleh 3 responden yang sama dengan uji tingkat harum. Pengamatan warna kayu dilakukan pada hari 14 HSI.

Uji Keberadaan Terpenoid. Bagian batang kayu yang dilukai dengan masa inokulasi 21 HSI, dipisahkan dari bagian kayu yang tidak menunjukkan perubahan warna. Kemudian kayu-kayu tersebut dicacah untuk selanjutnya diuji keberadaan terpenoidnya dengan menggunakan uji Lieberman-Burchard (Harborne 1987). Cacahan kayu diberi larutan etanol sebanyak $5 \mathrm{ml}$ kemudian dipanaskan hingga timbul gelembung pada etanol. Selanjutnya disaring dengan menggunakan kertas saring pada cawan petri steril. 
Kemudian diuapkan hingga mengering dan terbentuk endapan berwarna kuning. Kemudian ditambahkan $1 \mathrm{ml}$ dietil eter terhadap endapan tersebut dan dihomogenisasi. Selanjutnya larutan tersebut dipindahkan ke dalam tabung reaksi steril dan diberi 3 tetes asam asetat anhidrat dan 1 tetes $\mathrm{H} 2 \mathrm{SO} 4$ pekat. Warna merah atau ungu yang terbentuk pada endapan menunjukkan adanya senyawa triterpenoid. Kemudian ditambahkan $5 \mathrm{ml}$ etanol absolut pada larutan tersebut lalu diukur absorbansinya dengan spektrofotometer $\mathrm{nm}$ pada $\lambda 268 \mathrm{~nm}$. Nilai keberadaan senyawa terpenoid pada kayu gaharu yang berwarna hitam ditunjukkan dengan nilai absorbansi hasil ekstraksi senyawa gaharu. Semakin tinggi nilai absorbansi hasil ekstraksi menunjukkan semakin pekat senyawa terpenoid yang ada pada kayu gaharu. Nilai absorbansi tersebut dipergunakan untuk menentukan konsentrasi senyawa terpenoid melalui konversi menggunakan kurva standar terpenoid dari minyak gaharu alami. Dalam penentuan konsentrasi senyawa gaharu, yang dipakai sebagai pembanding adalah minyak gaharu asal Kalimantan.

Analisis data. Data kadar harum dan kadar warna dianalisis menggunakan uji Kruskal Wallis dilanjutkan dengan uji perbandingan berganda. Data selisih daun sisa dan uji terpenoid dianalisis dengan ANOVA pada $\alpha=5 \%$ bila perlakuan berpengaruh nyata maka setiap perlakuan dibandingkan dengan menggunakan uji lanjut Duncan pada taraf kepercayaan $95 \%$.

\section{HASIL}

\section{Tingkat Gugur Daun}

Bibit tanaman A. crassna mengalami tingkat keguguran daun yang berbeda pada tiap perlakuan. Persentase keguguran daun dari semua perlakuan kombinasi media tanam dan inokulum cendawan Acremonium sp. lebih tinggi dibandingkan dengan gugur daun pada bibit yang diinduksi dengan cendawan Fusarium sp. (Gambar 1).

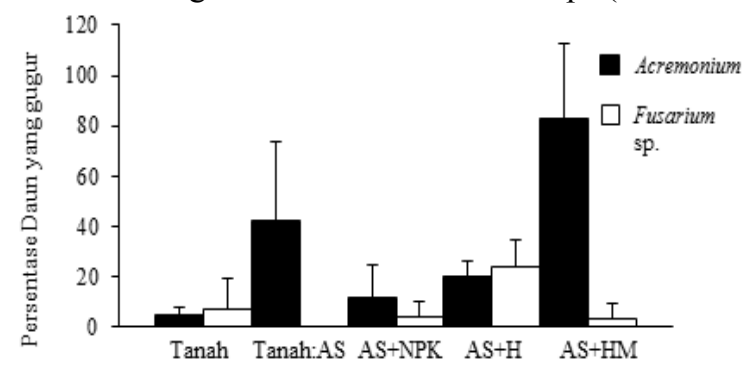

Gambar 1 Persentase gugur daun A. crassna akibat perlakuan kombinasi media tanam dengan cendawan Acremonium sp. dan Fusarium sp.

Faktor cendawan dan media tanam berpengaruh nyata pada kerontokkan daun $(\mathrm{p}<0,05)$, sedangkan interaksi keduanya tidak berpengaruh nyata $(p>0,05)$. Persentase gugur daun terendah terdapat pada perlakuan kombinasi AS dan Tanah yang diberi inokulum cendawan Fusarium sp.. Dari hasil penelitian ini juga diperoleh data bahwa pada perlakuan AS+NPK dengan inokulum Fusarium sp. sempat terjadi pertambahan tunas daun meski pada akhirnya tidak berkembang dan gugur. Sebelum gugur, beberapa daun A. crassna menguning/ klorosis dan beberapa daun mengalami nekrosis di tepi daun. Beberapa tanaman pada perlakuan inokulasi Acremonium menggugurkan semua daunnya, namun memiliki kebugaran pohon yang baik (Gambar 2).

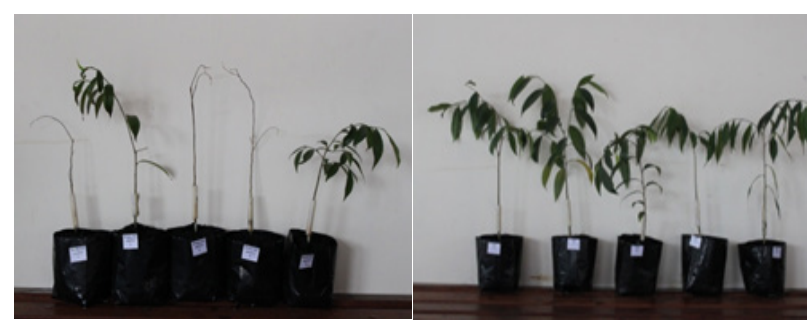

Gambar 2 Perbandingan kebugaran bibit pohon A. crassna akibat perlakuan AS+NPK Acremonium sp. (kiri) dan perlakuan AS+HM Fusarium sp. (kanan).

\section{Kadar Harum}

Berdasarkan hasil uji Kurskal Wallis diperoleh hasil bahwa kadar harum berbeda nyata antar perlakuan pada hari 3, 4, 5, 6, 9, 10, dan 14 HSI. Kadar harum pada masing-masing perlakuan menunjukkan variasi kadar harum. Puncak kadar harum tiap perlakuan juga menunjukan variasi waktu berdasarkan hari setelah inokulasi. Kadar harum pada perlakuan yang menggunakan cendawan Acremonium sp. cenderung lebih tinggi dibanding Fusarium sp. (Gambar 3 \& 4). Kadar harum pada perlakuan $\mathrm{AS}+\mathrm{H}$ dengan inokulum cendawan Acremonium sp. meningkat tajam saat 5 HSI (Gambar 3). Di sisi lain, kadar harum pada perlakuan AS+NPK dengan inokulum Acremonium sp. meningkat mulai 4 HSI kemudian menurun setelah 6 HSI. Perlakuan dengan cendawan Acremonium sp. (AS+H, AS+HM, dan tanah:AS) memberi respon wangi lebih rendah dibanding perlakuan AS+NPK.

Perlakuan AS+HM dengan inokulum cendawan Fusarium sp. mencapai puncak wangi lebih dahulu dibanding perlakuan Fusarium sp. yang lain (Gambar 4) saat 5 HSI dan menurun setelah 9 HSI. Perlakuan dengan cendawan Fusarium sp. lainnya (tanah, tanah:AS, AS+NPK, danAS+H) mempunyai kadar harum lebih rendah daripada perlakuan $\mathrm{AS}+\mathrm{HM}$.

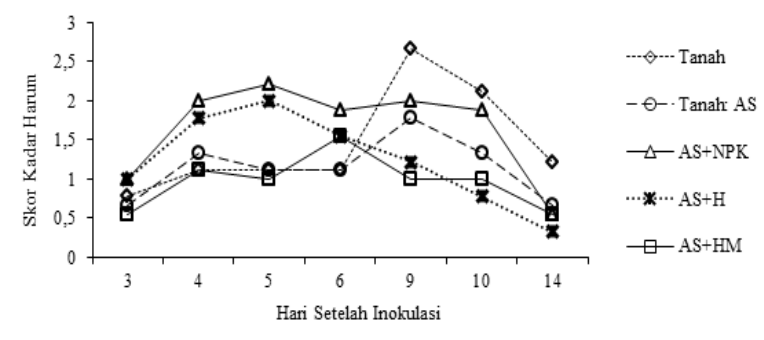

Gambar 3 Pengaruh kombinasi media tanam dan unsur hara terhadap kadar harum $A$. crassna yang diinduksi dengan Acremonium sp. 


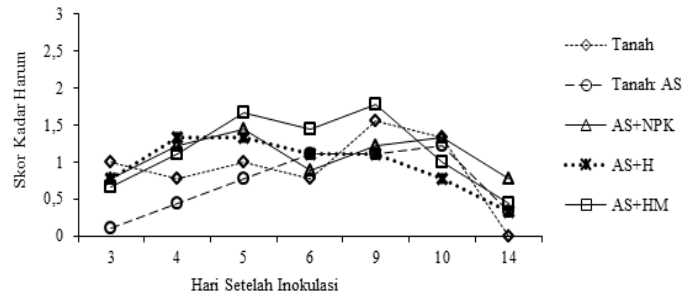

Gambar 4 Pengaruh kombinasi media tanam dan unsur hara terhadap kadar harum A. crassna yang diinduksi dengan Fusarium sp.

\section{Kadar Warna Kayu}

Hasil skoring warna kayu gaharu meliputi warna putih, putih kecokelatan, cokelat, hingga cokelat kehitaman (Gambar 5). Pengamatan pada parameter warna kayu menunjukkan warna tergelap (cokelat kehitaman) teramati pada perlakuan AS+NPK dengan inokulum cendawan Acremonium sp. dan Fusarium sp., sedangkan warna kayu paling terang (putih) dihasilkan oleh perlakuan kontrol (Tanah) dengan inokulum cendawan Acremonium sp. Secara keseluruhan perlakuan dengan cendawan Acremonium sp. menghasilkan kadar warna kayu yang lebih gelap dibanding Fusarium sp., kecuali pada kontrol dan pada perlakuan Tanah: AS (Gambar 6). Besaran nilai kepekatan warna kayu dapat dilihat juga dari hasil analisis Kurskal Wallis yang memberi peringkat kepekatan melalui perhitungan nilai tengah/ mean rank.

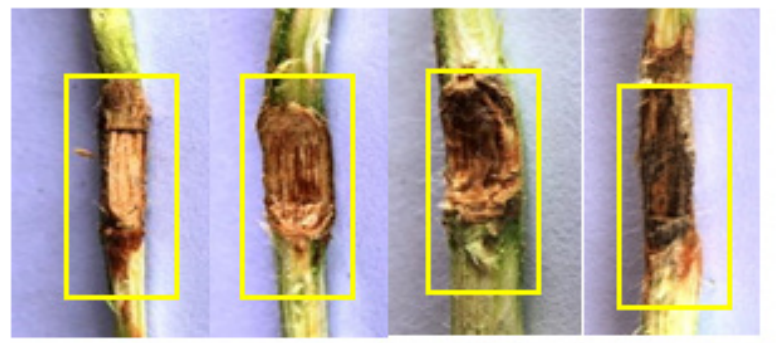

Skor $0 \quad$ Skor $1 \quad$ Skor $2 \quad$ Skor 3

Gambar 5 Perbandingan warna kayu A. crassna setelah diinduksi dengan skala 0-3. Skor 0: putih, 2: putih kecoklatan, 3: cokelat, 4: coklat kehitaman (Ket: bagian gambar yang di dalam kotak adalah bagian pohon yang diskoring)

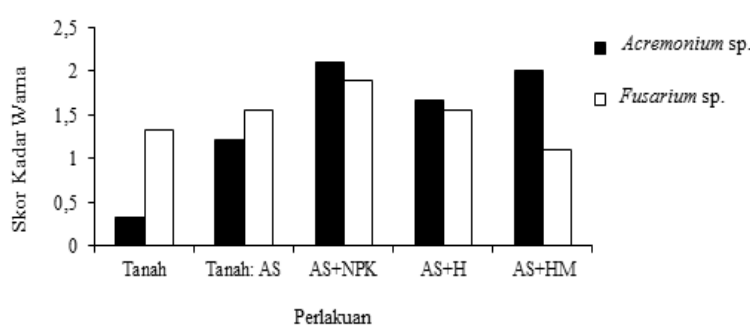

Gambar 6 Pengaruh kombinasi media tanam dan unsur hara terhadap kadar warna $A$. crassna yang diinduksi cendawan Acremonium sp. dan Fusarium sp.

\section{Keberadaan Terpenoid}

Hasil uji Lieberman-Burchard menunjukkan senyawa terpenoid dari kayu terdeteksi pada 21 HSI. Tidak terbentuk endapan warna merah yang menunjukkan adanya senyawa triterpenoid penghasil gaharu, tetapi ada sedikit warna hijau yang terbentuk. Berdasarkan analisis ANOVA bahwa nilai absorbansi faktor tunggal berbeda nyata antar kombinasi media begitu pula perlakuan inokulum cendawan $(\mathrm{p}<0,05)$, sedangkan untuk interaksi antara perlakuan media dan inokulum cendawan tidak ada interaksi $(\mathrm{p}>0,05)$. Keberadaan terpenoid yang paling tinggi terdapat pada perlakuan AS+NPK, karena nilai absorbansi yang diperoleh paling tinggi dibanding perlakuan lainnya (Tabel 1).

Tabel 1 Konsentrasi senyawa terpenoid pada kayu A. crassna dengan perlakuan kombinasi media tanam dan inokulum cendawan Acremonium sp. dan Fusarium sp. saat dua MSI

\begin{tabular}{cc}
\hline Perlakuan & $\begin{array}{c}\text { Konsentrasi senyawa } \\
\text { terpenoid }(\mathrm{ppm})\end{array}$ \\
\hline Tanah & $11,5 \mathrm{~b}$ \\
Tanah : AS & $10,4 \mathrm{bc}$ \\
AS+NPK & $44,3 \mathrm{a}$ \\
AS+H & $3,8 \mathrm{bc}$ \\
AS+HM & $2 \mathrm{c}$ \\
\hline
\end{tabular}

Ket: Angka yang diikuti dengan huruf yang sama menunjukkan tidak berbeda nyata berdasarkan uji Duncan pada $\alpha=0,05$

\section{PEMBAHASAN}

\section{Efektivitas Inokulasi}

A. crassna yang diinduksi dengan cendawan Acremonium sp. menggugurkan daun lebih banyak dibanding diinduksi dengan Fusarium sp.. Cendawan Acremonium sp. adalah salah satu cendawan yang dapat menginduksi pembentukan senyawa gaharu pada genus pohon Aquilaria (Rahayu et al. 1999). Selain itu Agustini et al. (2006) juga menemukan bahwa $F$. solani dan $F$. tricinctum berhasil diisolasi dari batang pohon Aquilaria spp. yang telah menghasilkan gaharu. Kedua cendawan tersebut merupakan cendawan busuk batang yang memiliki kemampuan menginduksi tanaman penghasil gaharu untuk menghasilkan gaharu. Namun, pada penelitian ini ditemukan perbedaan patogenitas antara dua cendawan ini dengan indikasi gugur daun. Perlakuan AS+NPK yang diberi inokulum Fusarium sp. sempat mengalami pertambahan tunas daun, tetapi pada akhirnya tunas tersebut tidak berkembang dan gugur. Pertambahan tunas ini mungkin karena kandungan nitrogen yang terdapat pada media tanam merangsang pertumbuhan batang, cabang dan daun, sedangkan kalium pada tanaman memperkuat tubuh tanaman sehingga organ tanaman tidak mudah gugur, juga sebagai sumber kekuatan ketika tanaman mengalami kekeringan dan penyakit (Lingga \& Marsono 2008). Klorosis pada daun umumnya dijumpai pada hampir seluruh perlakuan pada percobaan ini, klorosis diduga terjadi 
karena jalur distribusi floem terganggu akibat pengupasan batang untuk inokulasi serta infeksi dari cendawan pada batang $A$. crassna. Gugur daun dan klorosis merupakan respon tanaman terhadap cekaman sebagai tanda awal pohon terinfeksi dan diduga disertai dengan pembentukan senyawa pembentuk gaharu (Sumadiwangsa \& Zulnely 1999).

Perlakuan kombinasi media tanam AS $+\mathrm{HM}$ dan cendawan Acremonium sp. merupakan perlakuan dengan tingkat persentase gugur daun yang tertinggi. Pada penelitian ini penambahan sulfur pada larutan Hoagland (AS+HM) menyebabkan daun lebih banyak gugur dibanding perlakuan $\mathrm{AS}+\mathrm{H}$ yang tidak diberi penambahan sulfur. Unsur S merupakan salah satu bagian penting dari ferodoksin, suatu komplex Fe dan S yang terdapat dalam kloroplas (Danapriatna 2008). Sulfur dapat berfungsi sebagai pembentuk klorofil. Namun, kadar sulfur yang agak tinggi akan bersifat racun bagi tanaman. Keguguran daun yang terjadi pada perlakuan AS+HM diduga selain karena serangan cendawan juga disebabkan karena pemberian tambahan sulfur yang tidak tertoleransi oleh tanaman A. crassna yang diuji. Sulfur dengan komposisi yang tepat juga dapat merangsang pembentukan akar dan buah serta dapat mengurangi serangan penyakit (Tisdale et al. 1990).

Perubahan warna kayu terjadi pada semua perlakuan. Perubahan warna kayu disebabkan oleh serangan patogen, pelukaan dan senyawa kimia (Walker et al. 1997). Perubahan warna kayu tersebut juga dapat mengindikasi keberadaan senyawa gaharu. Perubahan warna kayu dari putih menjadi cokelat kehitaman adalah gejala awal pembentukan senyawa gaharu (Sumadiwangsa \& Zulnely 1999). Intensitas warna kayu bervariasi antar cendawan dan perlakuan kombinasi media tanam dan hara. Kadar warna terpekat diperoleh dari perlakuan AS+NPK dengan induksi cendawan Acremonium sp. yaitu cokelat kehitaman. Acremonium sp. dapat merangsang pembentukan fitoaleksin. Senyawa fitoaleksin pada tanaman gaharu dideposit pada kayu dan akan menyebabkan perubahan warna (Rahayu \& Situmorang 2006).

Kadar warna yang teramati menunjukkan mutu kayu yang dihasilkan memiliki ciri warna kayu putih kecokelatan hingga coklat kehitaman. Masa induksi yang pendek pada penelitian ini (21 hari) membuat klasifikasi mutu kayu tidak dapat dimasukkan dalam persyaratan mutu kemedangan. Klasifikasi mutu gaharu tingkat 1 adalah gubal gaharu yang berwarna hitam kecokelatan hingga hitam merata (BSN 1999). Perubahan warna kayu sangat dipengaruhi oleh masa induksi, semakin lama masa induksi warna yang dihasilkan semakin meningkat dan kualitas gaharu semakin baik (Rahayu \& Situmorang 2006). Intensitas warna tidak memiliki korelasi dengan kadar harum gaharu selama 2 minggu setelah tanam (MST), sehingga intensitas warna yang tinggi belum tentu memiliki kadar harum yang tinggi. Hal ini sesuai pernyataan Murtaip (2010) bahwa warna dan wangi adalah kriteria yang independent dalam penentuan mutu gaharu.

Aquilaria crassna yang diinduksi dengan cendawan
Acremonium sp. dan Fusarium sp. menunjukkan terjadi perubahan tingkat keharuman dari 1 HSI hingga 14 HSI. Tingkat keharuman antar tanaman mengalami puncak wangi yang berbeda pada tiap perlakuan. Muncularoma wangi pada kayu gaharu setelah diinduksi disebabkan oleh senyawa gaharu yang terakumulasi pada kayu tersebut. Perlakuan AS+NPK yang diinduksi dengan Acremonium sp. menghasilkan kadar harum yang lebih stabil dibanding perlakuan dengan Acremonium lainnya. Pupuk NPK diduga mampu mengoptimalkan metabolisme primer pada $A$. crassna yang diinduksi. Senyawa gaharu merupakan metabolit sekunder yang dibentuk dari metabolit primer (Rahayu \& Situmorang 2006). Jika tanaman mampu melakukan metabolisme dengan baik, maka tanaman akan mampu melakukan metabolisme sekunder. Kadar harum yang dihasilkan Acremonium sp. lebih tinggi dibanding Fusarium sp. mungkin disebabkan perbedaan kemampuan unsur hara untuk mempengaruhi aktivitas Acremonium sp. dan Fusarium sp. dalam menginduksi pembentukan senyawa harum pada gaharu. Pada perlakuan dengan Fusarium sp., didapat hasil bahwa perlakuan $\mathrm{AS}+\mathrm{HM}$ yaitu Hoagland yang diberi penambahan sulfat menghasilkan kadar harum yang konstan dan lebih baik daripada perlakuan Fusarium sp. lainnya.

\section{Pembentukan senyawa gaharu dan metabolisme sulfur}

Pemberian tambahan sulfat dapat meningkatkan wangi pada perlakuan Hoagland termodifikasi (AS+HM). Menurut Tisdale et al. (1990), sulfur terdapat dalam senyawa-senyawa yang mudah menguap yang menyebabkan rasa dan bau pada rumput-rumputan dan bawang-bawangan. Hal ini diperkuat oleh pernyataan Marschner (1995) bahwa hasil dari asimilasi sulfat dapat menghasilkan metabolit berupa senyawa volatil dengan wangi yang karakteristik, sehingga peningkatan keharuman gaharu yang diberi tambahan sulfat diduga dipengaruhi hal tersebut.

Senyawa yang menghasilkan harum pada tanaman gaharu berasal dari senyawa terpenoid golongan sesquiterpenoid yang dikenal dengan istilah sesquiterpen aromatik. Sesquiterpen merupakan salah satu dari beberapa metabolit sekunder yang berasal dari biosintesis isopentenil dan dimetilalil pirofosfat (Taiz \& Zeiger 2010). Metabolisme sekunder yang menghasilkan senyawa terpenoid ini dapat terjadi melalui dua jalur yang berbeda, yaitu jalur mevalonat atau jalur methylerythritol phospate (MEP). Kedua jalur tersebut akan menghasilkan isopentenil difosfat atau dimetilallil difosfat yang dapat membentuk senyawa sesquiterpen. Senyawa terpenoid tersebut adalah hasil dari metabolit sekunder yang diproduksi tumbuhan sebagai respon terhadap luka dan infeksi cendawan (Nobuchi \& Sripatanadilok 1991). Namun, hubungan antara asimilasi sulfat dan jalur mevalonat untuk pembentukan senyawa terpenoid belum dapat diketahui dengan pasti, sehingga kedua proses tersebut belum dapat dihubungkan secara langsung.

Kandungan keberadaan terpenoid paling tinggi terdapat pada perlakuan kombinasi media tanam dengan 
pupuk NPK. Namun, secara keseluruhan kandungan terpenoid yang diperoleh sangat rendah pada 21 HSI. Beberapa perlakuan menghasilkan sedikit warna hijau ketika di uji. Warna hijau mengindikasikan yang terbentuk adalah senyawa sterol. Sterol adalah salah satu senyawa yang tergolong ke dalam terpenoid (Harborne 1987). Keberadaan terpenoid diduga belum dapat terakumulasi pada tanaman karena masa induksi yang singkat. Namun, hasil penelitian Putri (2007) bahwa pemberian Acremonium sp. pada A. crassna terbukti dapat merangsang pembentukan senyawa terpenoid.

\section{SIMPULAN}

Kadar harum yang lebih baik terdapat pada perlakuan kombinasi media tanam AS+ NPK dengan Acremonium sp. dan AS $+\mathrm{HM}$ dengan Fusarium sp. dengan rentang waktu pengamatan selama 14 HSI. Kadar warna tergelap untuk inokulum Acremonium sp. dan Fusarium sp. terdapat pada perlakuan kombinasi media tanam AS+NPK. Keberadaan terpenoid belum dapat terakumulasi dalam 21 HSI. Acremonium sp. mengakibatkan kebugaran pohon lebih rendah dibanding Fusarium sp..

\section{DAFTAR PUSTAKA}

Agustini L, Wahyuno D, Santoso E. 2006. Keanekaragaman Jenis Jamur yang Potensial dalam Pembentukan Gaharu dari Batang Aquilaria spp.. Jurnal Penelitian Hutan dan Konservasi Alam vol. III no. 5: 555-564.

Barden A, Anak N, Mulliken T, Song M. 2000. Heart of the matter. Agarwood use and trade and CITES implementation Aquilaria malaccencis. Cambridge: TRAFFIC International.

[BSN] Badan Standarisasi Nasional. 1999. SNI 01/5009. 1-1999 Gaharu. Jakarta: Badan Standarisasi Nasional Indonesia.

Danapriatna N. 2008. Peranan sulfur bagi pertumbuhan tanaman. J Univ Islam 45 Bekasi Vol 9(1): 153-166.

Harborne JB. 1987. Metode Fitokimia. Padmawinata K dan I Sudiro, penerjemah. Bandung: Institut Teknologi Bandung. Terjemahan dari: Phytochemical Methods.

Isnaini, Y. 2004. Induksi Produksi Gubal Gaharu Melalui Inokulasi Cendawan dan Aplikasi Faktor Abiotik [Tesis]. Bogor: Fakultas Pertanian, Institut Pertanian Bogor.

Karyantara, ID. 2009. Pengaruh Beberapa Media Tanam Terhadap Pertumbuhan Tanaman Gaharu (Aquilaria beccariana van Tiegh.) [Skripsi]. Bogor: Fakultas Kehutanan, Institut Pertanian Bogor.

Lingga P, Marsono. 2008. Petunjuk Penggunaan Pupuk. Cet. 26. Jakarta: Penebar Swadaya.

Marschner H. 1995. Mineral Nutrition of Higher Plants. 2nd Edition. London: Academic Press

Merk-Turk F. 2002. Phytoaleksin: defence or just respon to stress? J. Cell Mol Biol 1:1-6.

Michiho I. 2005. Introduction of sesquiterpenoid production by methyl jasmonate in Aquilaria sinensis cell suspension culture. Essential Oil Research. http/ www.findarticles.com [12 februari 2006].

Murtaip. 2010. Induksi senyawa gaharu melalui kombinasi senyawa kimia dan Acremonium [Tesis]. Bogor: Fakultas Matematika dan Ilmu Pengetahuan Alam, Institut Pertanian Bogor.

Newton AC, Soehartono T. 2001. CITES and the Conservations of Tree Species: the Case of Aquilaria in Indonesia. Int Forest Rev (3): 27-33.

Nobuchi T, Siripatanadilok S. 1991. Preliminary observation of Aquilaria crassna wood associated with the formation of aloewood. Bull kyoto univ forest 63: 226-235.

Novriyanti E. 2008. Peranan zat ekstraktif dalam pembentukan gaharu pada Aquilaria crassna Pierre ex Lecomte dan Aquilaria microcarpa Baill [Tesis]. Bogor: Fakultas Kehutanan, Institut Pertanian Bogor.

Putri A. 2007. Induksi Pembentukan Wangi dan Senyawa Terpenoid pada Pohon Gaharu (Aquilaria crassna) dengan Acremonium sp. dan Metil Jasmonat (MeJA) [Skripsi]. Bogor: Fakultas Matematika dan Ilmu Pengetahuan Alam, Institut Pertanian Bogor.

Rahayu G, Isnaini Y, Umboh MIJ. 1999. Potensi Hifomiset dalam menginduksi Pembentukan Gubal Gaharu. Prosiding Kongres Nasional XV dan Seminar Perhimpunan Fitopatologi Indonesia; Purwokerto, 16-18 September 1999. Purwokerto: Perhimpunan Fitopatologi Indonesia. Hlm 573-581.

Rahayu G, Situmorang J. 2006. Menuju produksi senyawa gaharu secara lestari. Laporan Penelitian Hibah Bersaing XI. Bogor: Lembaga Penelitian Masyarakat. IPB.

Rosita, R. 2008. Efektivitas Pemberian Metil Jasmonat Secara Berulang Dalam Meningkatkan Deposit Senyawa Terpenoid Pada Pohon Gaharu (Aquiaria crassna) [Skripsi]. Bogor: Fakultas Matematika dan Ilmu Pengetahuan Alam, Institut Pertanian Bogor.

Sumadiwangsa S, Zulnely. 1999. Catatan mengenai gaharu di Kalimantan Timur dan Nusatenggara Barat. Info Hasil Hutan 5(2):80-90.

Taiz L, Zeiger E. 2010. Plant Physiology (5th Ed). Massachusetts: Sinauer Associates, Inc., Publishers.

Tarigan K. 2004. Profil Pengusahaan (Budidaya) Gaharu. Jakarta: Departemen Kehutanan Pusat Bina Penyuluhan Kehutanan.

Tisdale, SL, Nelson WL, Beaton JD. 1990. Soil fertility and fertilizers. (5th Ed). New York: Macmillan.

Walker D, Taylor RW, Mulrooney RP. 1997. Diagnosing Field Crop Problems. [terhubung berkala]. http:// ag.udel.edu/extension. [10 juni 2011].

Wulandari, E. 2009. Efektivitas Acremonium sp. dan Fusarium sp. Sebagai Penginduksi Ganda Terhadap Pembentukan Gaharu Pada Pohon Aquilaria microcarpa [Skripsi]. Bogor: Fakultas Matematika dan Ilmu Pengetahuan Alam, Institut Pertanian Bogor.

Yuan QS. 1995. Aquilaria species : in vitro culture and production of eaglewood (agarwood). Di dalam: Bajaj YPS, editor. Biotechnol Agric Forest 33. Volume ke-15. New York: Springer. Hlm: 36-46. 